\title{
Pityrogramma calomelanos, the Primary, Post-eruption Colonizer of Volcán Chichonal, Chiapas, Mexico
}

\author{
ROBERT A. SPICER \\ Life Sciences Department, Goldsmiths' College, Creek Road, London SE8 3BU, England \\ ROBYN J. BURNHAM \\ Department of Botany KB-15, University of Washington, Seattle, WA 98195 \\ PaUl Grant \\ Geology Department, Imperial College, London SW7 2BP, England \\ HARRY GLICKEN \\ U.S. Geological Survey, Cascades Volcano Observatory, 5400 MacArthur Blvd., \\ Vancouver, WA 98661
}

The southern Mexican Volcán Chichonal, otherwise known as "El Chichón," $\left(17^{\circ} 20^{\prime} \mathrm{N}, 93^{\circ} 12^{\prime} \mathrm{W}\right)$ erupted violently on 28 March 1982 at 2330 (local time), sending a column of ash and sulfur aerosol $16.8 \mathrm{~km}$ into the atmosphere. Further intermittent activity culminated in two major explosive eruptions on 3 April (1930 local time) and 4 April 1982 (0530 local time). During the final eruptions, column collapse gave rise to three major pyroclastic surges and flows that devastated $154 \mathrm{~km}^{2}$ of paratropical rain forest (sensu Wolfe, 1979) and agricultural land (Fig. 1). More complete descriptions of the eruptions are to be found in Varekamp et al. (1982), SEAN Bulletin (1982), Duffield et al. (1984) and Sigurdsson et al. (1985).

The pre-eruption vegetation of the area consisted of a patchwork of secondgrowth rain forest and local crops, which included cocoa, bananas, coffee, and maize. Numerous epiphytic pteridophytes were to be found in the area, with Selaginella aff. schizobasis Bak. (Burnham 001, BM, MEXU), Blechnum occidentale L. (Burnham 09, BM, MEXU), and Pteris grandifolia L. (Burnham 065, $\mathrm{BM}, \mathrm{MEXU}$ ) as frequent components of the ground cover.

The eruptions produced no lava flows, but trachyandesitic air-fall ash and pyroclastic surges and flows inundated a roughly circular area within a radius of approximately $6 \mathrm{~km}$ from the crater. The nature of the volcaniclastic deposits is described in detail in Sigurdsson et al. (1985). A particular feature of the eruptions was the large amount of sulfur ejected into the atmosphere (Thomas, 1982; Mroz \& Sedlacek, 1982; Rampino \& Self, 1984) and in the tephra (Varekamp \& Luhr, 1982; Luhr et al., 1982). Chemical analyses of the tephra are given in Hoffer et al. (1982) and Cochemé and Demant (1983).

High local annual precipitation $(>200 \mathrm{~cm}$ ) (Rzedowski, 1983) subsequently produced numerous erosional gulleys that have cut down, in some cases through several meters of volcanic debris, to the 1982 pre-eruption soil horizon.

In February 1984 we spent four weeks in the Chichonal area. The purpose of our visit was to study the formation of potential plant fossil deposits associated 


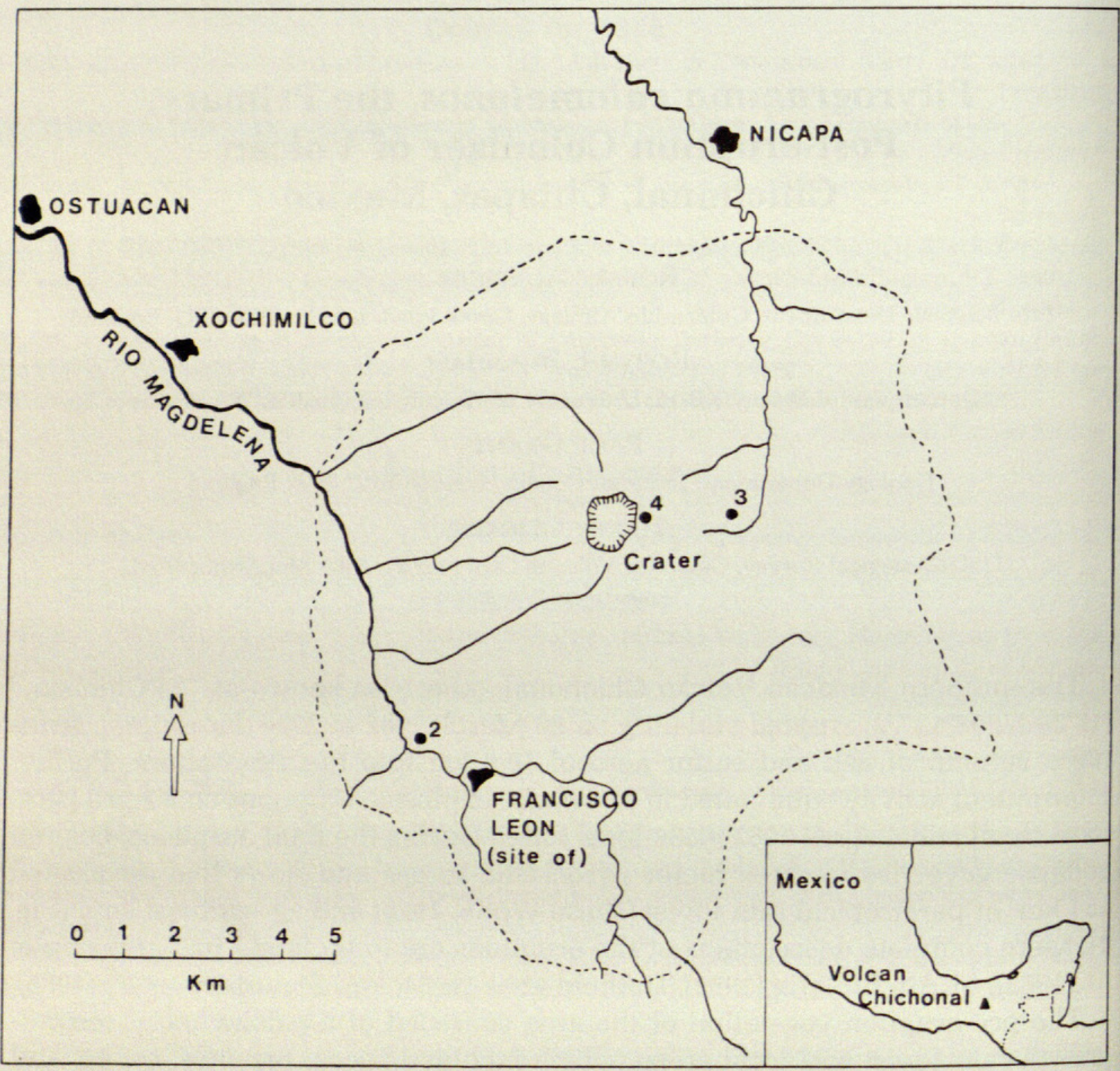

FIG. 1. Map of the Volcán Chichonal area. The dotted line indicates the approximate extent of the devastated area. Sites of Figs. 2-4 are indicated.

with the eruptions. This work involved studying plant and volcanic sediment distribution in the area, and it was immediately apparent that Pityrogramma calomelanos (L.) Link (Burnham 055, 058, BM, MEXU) was the primary colonizer wherever devastation of the pre-eruption vegetation had been intense. By February 1984 , fertile fronds of $P$. calomelanos, up to $1 \mathrm{~m}$ long, were observed to have regenerated from rhizomes in the 1982 pre-eruption soil horizon. Furthermore, this regrowth had apparently stabilized the soil against further erosion (Fig. 2). Regrowth from buried rhizomes accounted for the largest plants of Pityrogramma that were observed, but these only represented a small proportion of the overall population in the devastated area. By far the greatest number of individuals occurred as young sporophytes, typically $5-7 \mathrm{~cm}$ high, at densities of approximately 40 per $\mathrm{m}^{2}$ on stable, pumice-strewn slopes to within 1-2 km of the crater (Fig. 3). Young sporophytes were usually rooted in tephra the size of 


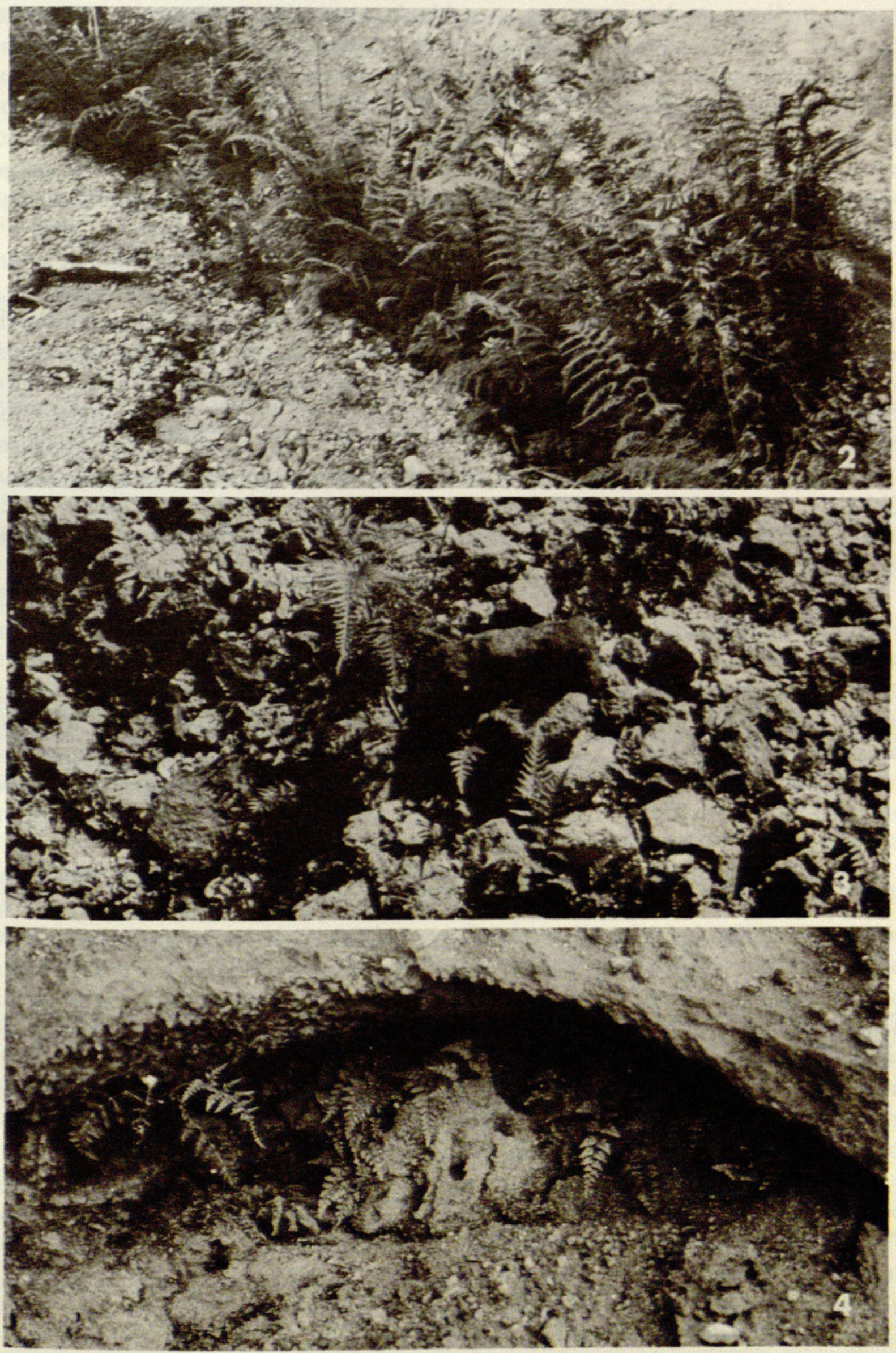

FIGs. 2-4. Pityrogramma calomelanos. 2. Plants regenerating from buried rhizomes in erosional gullies $5.3 \mathrm{~km}$ from crater. 3 . Young sporophytes on pumice-strewn slopes $2 \mathrm{~km}$ from crater. 4 . Plants in crevasses $200 \mathrm{~m}$ from crater rim. 
fine to medium sand between pumice blocks averaging $5-10 \mathrm{~cm}$ in maximum diameter. With decreasing distance from the crater, the sporophyte density decreased and became more patchy. However, sporophytes with fronds of $15 \mathrm{~cm}$ or so long were observed in small rock crevasses approximately $200 \mathrm{~m}$ east of the new crater rim (Fig. 4). Other notable occurrences were at the edge of eroded sulfur crusts surrounding non-active fumarolic sites on the distal lobes of large pyroclastic flows and on post-eruption flood deposits in the Río Magdelena river valley downstream from Ostuacán.

Pityrogramma is a genus native to tropical America. It is common in open habitats and is a colonizer of disturbed ground. Consequently it frequently occurs as a weed in palm and banana plantations (Tryon \& Tryon, 1982). Although some authors consider the genus to be native to Africa and Madagascar (Tryon \& Tryon, 1982), others consider it as introduced in the Old World, from where it has spread rapidly throughout the wet tropics (Schelpe, 1975). Its natural habitats include gravel bars in streams and rivers, rocky cliffs, and landslide areas, and it was noted as an early colonizer of laval flows on Mount Lamington, Papua (Schelpe, 1975). Schelpe (1975) stated that Pityrogramma was recorded on Krakatoa in 1906; he suggested that its arrival there was due to long-distance dispersal of spores by wind.

Because of the high sulfur content of the plume from Volcán Chichonal it is evident that $P$. calomelanos is tolerant of high sulfur concentrations in the substrate. Buried rhizomes were undoubtedly exposed to leached sulfurous compounds from the overlying volcaniclastics, and both prothalli and young sporophytes have been able to survive high local concentrations of sulfur in close proximity to fumaroles. In February 1984, sulfurous gases were still seeping from some pyroclastic flows, and large quantities of hydrogen sulfide were being given off from the crater. It would seem, therefore, that Pityrogramma is also tolerant of high concentrations of atmospheric sulfur and acidic rain.

Seed plants are recolonizing the devastated area, but none so prolifically as Pityrogramma. It is easy to see why this is so. The rhizomes are capable of surviving violent burial and some degree of thermal shock, and are able to produce fertile fronds relatively quickly. As with most homosporous pteridophytes, vast numbers of wind-dispersed spores are produced, any one of which has the capacity to produce a prothallus. Even if prothalli are spatially separated so as to prevent outcrossing, self-fertilization can give rise to a new sporophyte in a relatively short time. On the other hand, seed plants in the same situation may take longer to mature, flower, and set seed. Seeds are not produced in such large numbers as spores and are usually not dispersed so far.

High relative concentrations of monolete fern spores have recently been reported from coals immediately overlying an iridium-rich clay at the Cretaceous/ Tertiary boundary in New Mexico and Colorado (Pillmore et al., 1984). This fern "spike" is interpreted as representing the initial floral recovery phase following a possible terminal Cretaceous bolide impact as suggested by Alvarez et al. (1980). The present environment surrounding El Chichón is in some ways analogous to that hypothesized for the immediate post-impact terrestrial Tertiary ecosystem.

We thank the following for their kind assistance: Servando de la Cruz, UNAM; 
Mario Sousa and the staff of the Herbário Nacional de México; Sr. Isidro Chavez; the people of Ostuacán; and The Royal Society.

\section{LITERATURE Cited}

Alvarez, L. W., W. Alvarez, F. Asaro, and H. V. Michel. 1980. Extraterrestrial cause for the Cretaceous-Tertiary extinction. Science 208:1095.

Cochemé, J. J. and A. Demant. 1983. Naturaleza y composición del material emitido por el Volcán Chichonal, Chiapas (marzo-abril, 1982). In El Volcán Chichonal. Mexico, D.F.: Universidad Nacional Autónoma de México.

Duffield, W. A., R. I. Tilling, and R. Canul. 1984. Geology of El Chichón volcano, Chiapas, Mexico. J. Volc. Geotherm. Res. 20:117-132.

Hoffer, J., G. P. Filiberto, and P. MuelA. 1982. Eruption of El Chichón volcano, Chiapas, Mexico, 28 March to 7 April 1982. Science 218:1307-1308.

Luhr, J., I. S. E. CARMichael, and J. C. VAREKamp. 1982. Minerology and petrology of ejecta from the March-April 1982 eruptions of El Chichón volcano, Chiapas, Mexico. Eos. Trans. Amer. Geophys. Union 63:1126-1127.

Mroz, E. J. and W. A. SEDLACEK. 1982. Stratospheric aerosols from El Chichón. Eos. Trans. Amer. Geophys. Union 63:900.

Pillmore, C. L., R. H. Tschudy, C. J. Orth, J. S. Gilmore, and J. D. Knight. 1984. Geologic framework of nonmarine Cretaceous-Tertiary boundary sites, Raton Basin, New Mexico and Colorado. Science 223:1180-1183.

Rampino, M. R. and S. Self. 1984. The atmospheric effects of El Chichón. Sci. Amer. 250:34-43.

Rzedowski, J. 1983. Vegetación de México. Mexico, D.F.: Editorial Limusa.

SCHELPE, E.A.C.L.E. 1975. Observations on the spread of the American fern Pityrogramma calomelanos. Fern Gaz. 1:101-104.

SEAN Bulletin, Smithsonian Institution. 1982. Volcanic events: El Chichón. 7:2-6.

SiRgurdsson, H., S. N. CAREY, and J. M. EsPINDOLA. 1985. The 1982 eruptions of El Chichón volcano, Mexico: Stratigraphy of pyroclastic deposits. J. Volc. Geotherm. Res. (in press).

ThOMAs, G. E. 1982. Satellite observations of the El Chichón volcanic aerosol in the stratosphere. Eos. Trans. Amer. Geophys. Union 63:898.

TRYon, R. M. and A. F. TRYon. 1982. Ferns and allied plants with special reference to tropical America. New York: Springer-Verlag.

VAREKAMP, J. C. and J. LuHR. 1982. The 1982 eruption of El Chichón volcano: Nature of the eruption, ash and volatiles. Eos. Trans. Amer. Geophys. Union 63:1126.

,- K. PrestegaARD, and J. Canepa. 1982. The 1982 eruption of El Chichón volcano, Chiapas, Mexico. Part 1. Stratigraphy, volume and volatile element characteristics of the ash fall deposits. Geol. Soc. Amer. Abstr. Prog. 14:637.

WolfE, J. A. 1979. Temperature parameters of humid to mesic forests of eastern Asia and relation to forests of other regions of the northern hemisphere and Australasia. U.S. Geol. Surv. Prof. Paper 1106:1-37. 


\section{$2 \mathrm{BHL}$ Biodiversity Heritage Library}

Spicer, Robert A et al. 1985. "Pityrogramma calomelanos, the Primary, Post-Eruption Colonizer of Volcan Chichonal, Chiapas, Mexico." American fern journal 75, 1-5. https://doi.org/10.2307/1546571.

View This Item Online: https://www.biodiversitylibrary.org/item/100481

DOI: https://doi.org/10.2307/1546571

Permalink: https://www.biodiversitylibrary.org/partpdf/230519

\section{Holding Institution}

Missouri Botanical Garden, Peter H. Raven Library

\section{Sponsored by}

Missouri Botanical Garden

\section{Copyright \& Reuse}

Copyright Status: In copyright. Digitized with the permission of the rights holder.

License: http://creativecommons.org/licenses/by-nc-sa/3.0/

Rights: https://biodiversitylibrary.org/permissions

This document was created from content at the Biodiversity Heritage Library, the world's largest open access digital library for biodiversity literature and archives. Visit BHL at https://www.biodiversitylibrary.org. 